\title{
Formulasi Dan Uji Aktivitas Antiradikal Bebas Sediaan Gel Ekstrak Etanol Daun Bidara (Ziziphus mauritiana Lamk) Menggunakan Metode DPPH
}

\author{
Murniyati ${ }^{a, 1^{*}}$, Windah Anugrah Subaidah ${ }^{a, 2}$, Agus Dwi Ananto a,3 \\ a Program Studi Farmasi, Fakultas Kedokteran, Universitas Mataram, J1. Majapahit No.62, Dasan Agung Baru, Mataram, 83I26 \\ ${ }^{1}$ niamurniyati23@gmail.com*; ${ }^{2}$ windahanugrah@unram.ac.id; ${ }^{3}$ agus_da@unram.ac.id \\ *korespondensi penulis
}

INFO ARTIKEL

Diterima :

06-06-2021

Direvisi :

I2-07-202I

Disetujui :

I2-07-2021

\section{Kata kunci:}

Aktivitas Antiradikal

Bebas;

Daun Bidara;

Gel;

$\mathrm{DPPH}$.

\section{ABSTRAK}

Ekstrak daun bidara memiliki IC50 sebesar 4,9379 ppm dan daun bidara mengandung senyawa fenolik sehingga dapat digunakan sebagai antioksidan alami penangkal radikal bebas serta memiliki potensi yang dapat dikembangkan sebagai kosmetik salah satunya adalah sediaan gel. Tujuan penelitian ini adalah memformulasi sediaan gel ekstrak etanol daun bidara dan menguji aktivitas antiradikal bebas menggunakan metode DPPH. Daun bidara diekstraksi menggunakan metode maserasi dengan pelarut etanol 70\%. Gel dibuat dengan konsentrasi ekstrak 4\%, 5\% dan 6\%, selanjutnya dilakukan evaluasi sifat fisik meliputi organoleptis, homogenitas, uji $\mathrm{pH}$, uji daya sebar, dan uji daya lekat. Aktivitas antioksidan diuji dengan metode DPPH. Hasil menunjukkan ekstrak etanol daun bidara dapat diformulasikan menjadi sediaan gel antioksidan dengan variasi konsentrasi ekstrak 4\%, 5\% dan 6\%, dimana sediaannya memenuhi persyaratan sifat fisik yang baik. Gel ekstrak etanol daun bidara memiliki aktivitas antioksidan yang berbeda-beda berdasarkan variasi konsentrasi ekstrak. Peningkatan konsentrasi ekstrak menyebabkan perbedaan kemampuan pelepasan zat aktif yang ditunjukkan dengan nilai IC50 yang berbeda untuk sediaan 4\%, 5\% dan 6\% yaitu masing-masing sebesar 1679,874 ppm, I203,636 ppm dan $998,736 \mathrm{ppm}$. Berdasarkan nilai $\mathrm{IC}_{50}$, intensitas aktivitas penghambatan radikal bebas pada sediaan gel ekstrak etanol daun bidara tergolong lemah.

Key word:

Free Antiradical

Activity;

Bidara Leaf;

Gel;

DPPH.

\section{ABSTRACT}

Bidara leaf extract has an IC50 of 4.9379 ppm and bidara leaves contain phenolic compounds so that they can be used as natural antioxidants to ward off free radicals and have the potential to be developed as a cosmetic, one of which is a gel preparation. The purpose of this study was to formulate a gel preparation of bidara leaf ethanol extract and to test its anti-free radical activity using the DPPH method. Bidara leaves were extracted using maceration method with $70 \%$ ethanol as solvent. Gels were made with extract concentrations of $4 \%, 5 \%$ and $6 \%$, then evaluated for physical properties including organoleptic, homogeneity, $\mathrm{pH}$ test, spreadability test, and adhesion test. Antioxidant activity was tested by DPPH method. The results show that the ethanol extract of bidara leaves can be formulated into an antioxidant gel preparation with variations in extract concentrations of $4 \%, 5 \%$ and $6 \%$, where the preparation meets the requirements of good physical properties. The ethanol extract gel of bidara leaves has different antioxidant activities based on variations in the concentration of the extract. Increasing the concentration of the extract caused differences in the ability to release the active substance as indicated by different IC50 values for 4\%, 5\% and 6\% preparations, which were $1679,874 \mathrm{ppm}, 1203,636 \mathrm{ppm}$ and 998,636 ppm, respectively. Based on the IC50 value, the intensity of free radical inhibitory activity in the ethanol extract gel preparation of bidara leaves is classified as weak.

This is an open access article under the CC-BY-SA license. 


\section{Pendahuluan}

Radikal bebas merupakan senyawa yang memiliki elektron tidak berpasangan sehingga bersifat sangat reaktif dan tidak stabil. Ketidakstabilan akan menangkap elektron lain yang ada di sekelilingnya untuk menstabilkan bentuknya (Kurnia dan Taufikurrohman, 2017). Keberadaan radikal bebas dapat merusak kolagen dan elastin yaitu suatu protein yang menjaga kulit tetap lembab, halus, fleksibel dan elastis sehingga dapat memicu penuaan dini yang ditandai dengan munculnya keriput, sisik, kering, pecah-pecah, tampak kusam dan berkerut, kulit menjadi lebih cepat tua serta muncul flek-flek hitam (Maysuhara, 2009).

Penggunaan antioksidan sintetik dilaporkan dapat menimbulkan efek samping yang bersifat hepatotoksik dan karsinogenesis, sehingga pemanfaatan antioksidan alami menjadi salah satu alternatif yang dibutuhkan karena memiliki efek samping yang lebih rendah (Zeng dkk., 20I4).

Salah satu tanaman yang berkhasiat sebagai antiradikal bebas adalah daun bidara (Ziziphus mauritiana Lamk). Penelitian terkait yang pernah dilakukan oleh Maakh, dkk (2018) terhadap aktivitas antioksidan dari ekstrak etanol 70\% daun bidara menunjukkan nilai IC50 sebesar 4,9379 ppm dan mengandung senyawa fenolik seperti flavonoid, alkaloid dan tanin yang dapat berperan sebagai antioksidan dengan cara memberikan elektronnya atau menghentikan reaksi dari radikal bebas.

Pemilihan metode ekstraksi harus diperhatikan agar diperoleh hasil ekstraksi yang maksimal. Secara umum, metabolit sekunder seperti flavonoid, alkaloid dan tannin merupakan senyawa metabolit sekunder yang tidak tahan terhadap temperatur tinggi serta dapat teroksidasi oleh suhu yang tinggi (Koirewoa dkk., 2012). Oleh karena itu, penggunaan metode maserasi cocok digunakan untuk mendapatkan metabolit sekunder seperti flavonoid, alkalid dan tanin secara lebih baik. Selain metode ekstraksi, perlu diperhatikan pula pelarut ekstraksi yang digunakan. Pada penelitian ini digunakan pelarut etanol. Etanol merupakan pelarut polar yang cocok digunakan untuk menarik senyawa-senyawa polar seperti flavonoid, alkaloid dan tanin (Koirewoa dkk., 20I2).

Berdasarkan masalah tersebut, daun bidara berpotensi untuk dikembangkan dalam bidang kosmetik, salah satunya adalah diformulasikan dalam bentuk sediaan gel. Gel adalah sediaan semi padat berupa suspensi yang tersusun baik dari partikel anorganik atau organik dan terpenetrasi oleh suatu cairan. Sediaan gel memiliki beberapa keuntungan meliputi efek pendingin pada kulit saat digunakan, penampilan sediaan yang jernih dan elegan, elastis, mudah dicuci dengan air, pelepasan obatnya baik, kemampuan penyebarannya pada kulit baik dan relatif lebih stabil dalam penyimpanan (Nabi dkk, 2016; Rahmi, 2017). Namun hingga saat ini, belum adanya penelitian terkait formulasi sediaan gel ekstrak etanol daun bidara. Tujuan penelitian ini adalah memformulasi sediaan gel ekstrak etanol daun bidara dan menguji aktivitas antiradikal bebas menggunakan metode DPPH.

\section{Metode}

\section{Alat dan Bahan}

Alat-alat yang digunakan dalam penelitan ini adalah hotplate (Labnet $\left.{ }^{\circledR}\right)$, kuvet (QS®),

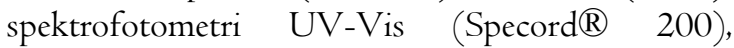
timbangan analitik (Kern $\left.{ }^{\circledR}\right)$, vortex (Labnet $\left.{ }^{\circledR}\right)$, $\mathrm{pH}$ meter O'hauss, waterbath, rotary evaporator.

Bahan-bahan dalam penelitian ini adalah daun bidara (Ziziphus mauritiana Lamk) diambil dari Kampung Melayu, Kota Bima, Nusa Tenggara Barat, asam asetat anhidrat p.a (Merck), asam askorbat p.a (Himedia), $\mathrm{FeCl}_{3} \mathrm{I} \%$ teknis (Merck), $\mathrm{HCl}$ pekat p.a (Merck), $\mathrm{HCl} 2 \mathrm{~N}$ (Merck), $\mathrm{H}_{2} \mathrm{SO}_{4}$ pekat p.a (Merck), kloroform p.a (Merck), etanol 70\% teknis (Merck), reagen Dragendorff p.a (Nitra Kimia), reagen Mayer p.a (Nitra Kimia), serbuk DPPH p.a (Sigma Aldrich), serbuk Mg p.a (Merck), karbopol 940, TEA, metil paraben, propilenglikol, dan gliserin.

\section{Persiapan Sampel Penelitian}

Sebanyak I,5 kg sampel daun bidara diambil dari Kampung Melayu, Kota Bima, Nusa Tenggara Barat. Sampel disortasi basah, dicuci, dirajang, dan dikeringkan dengan cara dijemur dibawah sinar matahari dengan dilapisi kain hitam. Hasil simplisia daun bidara disortasi kering kemudian dihaluskan dengan blender hingga diperoleh serbuk simplisia daun bidara.

\section{Pembuatan Ekstrak Etanol Daun Bidara dan Skrining Fitokimia}

Simplisia kering sebanyak 300 gram dimaserasi menggunakan pelarut etanol 70\% selama $3 \times 24$ jam, dimana penyarian ekstrak dilakukan setiap 24 jam, kemudian ditutup. Selanjutnya dimaserasi dengan menggunakan pelarut etanol $70 \%$ yang baru dan dilakukan pengadukan setiap 8 jam agar proses ekstraksi berjalan maksimal. Ekstrak yang diperoleh dikumpulkan dan dipekatkan menggunakan rotary evaporator dan diuapkan di waterbath hingga memperoleh ekstrak kental.

Rendeman $=\frac{\text { bobot ekstrak kental }}{\text { bobobt serbuk simplisia }} \times 100 \%$ 
Ekstrak etanol daun bidara dilakukan skrining fitokimia untuk mengetahui adanya kandungan flavonoid, alkaloid dan tanin. Sebanyak $2 \mathrm{ml}$ ekstrak ditambahkan serbuk $\mathrm{Mg}$ dan beberapa tetes $\mathrm{HCl}$ pekat, terbentuknya warna merah, kuning atau jingga menandakan adanya flavonoid (Alamsyah, dkk., 20I4). Sebanyak 2 gram ekstrak kental, ditambahkan I $\mathrm{ml} \mathrm{HCl} 2 \mathrm{~N}$, disaring dan ditambahkan 2-3 tetes pereaksi mayer dan dragendorff. Endapan putih (pereaksi mayer) dan endapan merah/jingga (pereaksi dragendorff) menandakan adanya alkaloid (Tiwari, dkk., 20II). Sebanyak $2 \mathrm{ml}$ ekstrak ditambahkan beberapa tetes $\mathrm{FeCl}_{3} \mathrm{I} \%$ akan terbentuk warna biru tua, biru kehitaman, atau hitam kehijauan menandakan adanya tanin (Padmasari, 2013).

\section{Pembuatan Sediaan Gel Ekstrak Daun Bidara}

Ekstrak dibuat dengan variasi konsentrasi 4\%, $5 \%$, dan 6\% dapat dilihat pada tabel I. Karbopol 940 dikebangkan menggunakan aquades, digerus hingga homogen (campuran I). Kemudian metil paraben dilarutkan dalam propilenglikol dan gliserin, lalu dihomogenkan (campuran 2). Campuran I ditambah campuran 2 digerus sampai homogen dan ditambahkan TEA sedikit demi sedikit hingga membetuk basis gel dengan konsistensi yang kental, bersifat jernih dan transparan. Selanjutnya ditambahkan ekstrak kental daun bidara sebagai zat aktif antioksidan sedikit demi sedikit ke dalam basis gel dan dihomogenkan. Sediaan gel ditambahkan aquades sedikit demi sedikit hingga diperoleh sediaan dengan massa 50 gram.

Tabel I. Formula Sediaan Gel Ekstrak Etanol Daun Bidara

\begin{tabular}{ccccc}
\hline Komponen & FI (4\%) & F2 (5\%) & F3 (6\%) & Fungsi \\
\hline Ekstrak & 4 & 5 & 6 & Zat aktif \\
Karbopol & I & I & I & Gelling agent \\
TEA & I,2 & I,2 & I,2 & Pengatur pH \\
Gliserin & I0 & I0 & I0 & Humektan \\
Propilen glikol & I5 & I5 & I5 & Humektan \\
Metil paraben & 0,2 & 0,2 & 0,2 & Pengawet \\
Aquades & Ad 50 & Ad 50 & Ad 50 & Pelarut \\
\hline
\end{tabular}

\section{Evaluasi Sifat Fisik Gel}

Uji organoleptis dilakukan pengamatan secara langsung dengan mengamati bentuk, warna dan bau secara visual (Ismarani dkk, 20I4).

Uji homogenitas dilakukan dengan mengoleskan gel pada kaca objek sebanyak 0,5 g, diamati adanya butir-butir kasar atau tidak. Gel menunjukkan susunan yang homogen apabila tidak terlihat adanya butiran-butiran kasar (Ardana dkk, 20I5).

Uji pH dilakukan dengan melarutkan I gram gel dalam $50 \mathrm{ml}$ aquades kemudian diukur $\mathrm{pH}$ campuran menggunakan $\mathrm{pH}$ meter O'hauss dan dilakukan replikasi (Ismarani dkk, 20I4).

Uji daya sebar dilakukan dengan meletakkan gel ditengah kaca sebanyak 0,5 gram, ditutup dengan kaca lainnya dan dibiarkan selama I menit. Kemudian diukur diameter gel dengan mengambil panjang rata-rata diameter dari beberapa sisi. Kemudian perlakuan yang sama dilanjutkan dengan penambahan beban I00, I50, 200 gram dan dilakukan replikasi 3 kali pengukuran (Suardi dkk, 2008).

Uji daya lekat dilakukan dengan meletakkan gel sebanyak 0,5 gram di tengah kaca objek, ditutup dengan kaca lain dan ditekan dengan beban I kg diatasnya selama 5 menit. Kaca objek tersebut dipasang pada alat uji yang diberi beban 80 gram dan dihitung waktu yang diperlukan kedua kaca objek terlepas (Hastuty $\mathrm{dkk}, 2018$ ).

\section{Pengujian Aktivitas Antiradikal Bebas Sediaan Gel}

Penentuan panjang gelombang maksimum dilakukan dengan mengukur larutan DPPH 0,I mM pada panjang gelombang 400-600 nm sedangkan penentuan Operating Time (OT) dilakukan pengukuran tiap 5 menit selama 60 menit menggunakan vitamin $C$ konsentrasi 5 ppm dan DPPH (2:I) pada panjang gelombang maksimum (Hidayati dkk, 2017).

Pengujian antiradikal bebas vitamin $\mathrm{C}$ dibuat seri konsentrasi I ppm, 2 ppm, 3 ppm. 4 ppm dan 5 ppm. Pengukuran serapan vitamin $C$ dengan perbandingan sampel dan DPPH yaitu 2:I. Campuran tersebut divortex selama I menit, diinkubasi pada suhu kamar dan diukur serapan dengan spektrofotometer $U V$-VIS pada panjang gelombang maksimum (Maakh dkk, 20I8).

Pengujian antiradikal bebas sediaan gel dengan dibuat seri konsentrasi 200 ppm, 600 ppm, I000 ppm, I400 ppm dan I800 ppm. Pengukuran serapan sediaan gel dengan perbandingan sampel dan DPPH yaitu 2:I. Campuran tersebut divortex selama I menit, diinkubasi pada suhu kamar dan diukur serapan dengan spektrofotometer $U V$-VIS pada panjang gelombang maksimum (Maakh dkk, 20I8). 


\section{Analisis Data}

Analisis data yang diperoleh diolah secara statistik menggunakan SPSS I6. Analisis yang dilakukan uji normalitas (Shapiro-Wilk) dan uji homogenitas (uji Levene). Untuk melihat hubungan dan perbedaan antar kelompok perlakuan, dilakukan analisis One Way Anova kemudian dilanjutkan dengan uji Post Hoc Tukey pada sifat fisik gel dan analisis deskriptif kuantitatif untuk mengukur aktivitas antioksidan dari gel ekstrak etanol dan bidara dengan metode DPPH.

\section{Hasil dan Pembahasan}

\section{Persiapan Sampel}

Sebanyak I,5 $\mathrm{kg}$ sampel daun bidara yang diperoleh dari Kampung Melayu, Kota Bima, Nusa Tenggara Barat dibuat menjadi simplisia sebelum dilakukan proses ekstraksi. Sampel simplisia daun bidara dilakukan dengan cara disortasi basah, pencucian, perajangan, pengeringan, sortasi kering, pengemasan, dan penyimpanan (Prasetyo dan Inoriah, 2013). Kemudian dihaluskan dengan cara diblender sehingga diperoleh serbuk simplisia sebanyak 300 gram.

\section{Ekstraksi dan Skrining Fitokimia}

Metode maserasi merupakan metode cara dingin yang dapat menarik senyawa yang bersifat termolabil (Fauzi, dkk., 20I7). Proses maserasi dilakukan dengan cara serbuk simplisia sebanyak 300 gram dimaserasi menggunakan pelarut etanol 70\% dengan perbandingan I:7. Pelarut etanol 70\% digunakan karena pelarut tersebut memiliki gugus polar dan non polar sehingga memiliki kemampuan untuk menarik senyawa polar, semi polar dan non polar. Pemilihan etanol juga didasarkan pada senyawa yang akan ditarik, dimana pelarut polar akan menarik senyawa polar sedangkan palarut non polar akan menarik senyawa non polar (Depkes RI, 2000). Bobot ekstrak kental daun bidara yang diperoleh adalah 55,96 gram dengan \% rendemen sebesar 18,65\%. Persentase rendemen menggambarkan banyaknya senyawa bioktif yang terekstrak dari suatu tanaman. Hasil persentase rendemen dan organoleptis sampel daun bidara dapat dilihat pada tabel 2. Skrining fitokimia menunjukkan bahwa ekstrak daun bidara positif mengandung flavonoid, alkaloid dan tanin. Hasil skrining fitokimia dapat dilihat pada tabel 3.

\section{Pembuatan Sediaan Gel}

Selanjutnya ekstrak tersebut dibuat sediaan gel 50 gram dan dilakukan evaluasi sifat fisik sediaan meliputi uji organoleptis, uji homogenitas, uji $\mathrm{pH}$, uji daya sebar, dan uji daya lekat. Hasil evaluasi dapat dilihat pada tabel 4 .

Tabel 2. Hasil Persentase Rendemen dan Organoleptis Sampel Daun Bidara

\begin{tabular}{|c|c|c|c|c|c|}
\hline \multirow[t]{2}{*}{ Sampel } & \multirow{2}{*}{$\begin{array}{c}\text { Bobot } \\
\text { Ekstrak }\end{array}$} & \multirow{2}{*}{$\begin{array}{l}\text { Persentase } \\
\text { Rendemen }\end{array}$} & \multicolumn{3}{|c|}{ Organoleptis } \\
\hline & & & Bentuk & Warna & Bau \\
\hline $\begin{array}{l}\text { Daun } \\
\text { bidara }\end{array}$ & $55,96 \mathrm{gr}$ & $18,65 \%$ & Kental & $\begin{array}{c}\text { Hijau } \\
\text { kehitamar }\end{array}$ & $\begin{array}{l}\text { Khas } \\
\text { daun }\end{array}$ \\
\hline
\end{tabular}

Tabel 3. Hasil Skrining Fitokimia Ekstrak Etanol Daun Bidara

\begin{tabular}{cccc}
\hline Pengujian & Pereaksi & Hasil & Indikasi Positif \\
\hline Flavonoid & $\mathrm{Mg}, \mathrm{HCl}$ pekat & + & Terbentuk warna merah bata \\
Tanin & $\mathrm{FeCl}_{3} \mathrm{I} \%$ & + & Terbentuk warna hijau kehitaman \\
Alkaloid & Mayer & + & Terbentuk endapan putih \\
& Dragendorff & + & Terbentuk endapan merah jingga \\
\hline
\end{tabular}

Tabel 4. Hasil Evaluasi Sifat Fisik Sediaan Gel

\begin{tabular}{ccccc}
\hline \multirow{2}{*}{ Evaluasi } & Parameter & \multicolumn{3}{c}{ Konsentrasi } \\
\cline { 3 - 5 } & Kriteria & FI (4\%) & F2 (5\%) & F3 (6\%) \\
\hline Organoleptis & Warna & Hijau kekuningan & Hijau kekuningan & Hijau kecoklatan \\
& Bau & Khas ekstrak etanol & Khas ekstrak etanol & Khas ekstrak etanol \\
& & daun bidara & daun bidara & daun bidara \\
& Bentuk & Kental & Kental & Kental \\
Homogenitas & Homogen & Homogen & Homogen & Homogen \\
pH & $4-8$ & $6,5 \mathrm{I} \pm 0,03$ & $6,54 \pm 0,05$ & $6,75 \pm 0,0 I^{* *}$ \\
Daya Sebar & $3-7 \mathrm{~cm}$ & $4,02 \pm 0,09 \mathrm{~cm}^{*}$ & $5,96 \pm 0,1 \mathrm{~cm}$ & $5,62 \pm 0,08 \mathrm{~cm}^{* *}$ \\
Daya Lekat & $>4$ detik & $4,30 \pm 0,29$ detik & $4,06 \pm 0,44$ detik & $4,09 \pm 0,08$ detik \\
\hline
\end{tabular}

Keterangan : ${ }^{\star}=p<0,05$ 
Uji organoleptis sediaan gel yang diperoleh untuk sediaan $4 \%$ dan 5\% memiliki warna hijau kekuningan dan sediaan $6 \%$ memiliki warna hijau kehitaman dan berbau khas ekstrak etanol daun bidara dan karbopol sedangkan hasil uji homogenitas menunjukkan bahwa sediaan gel homogen, ditandai dengan tidak adanya partikel-partikel kasar sehingga dapat dikatakan bahwa semua bahan tercampur secara merata (homogen). Sediaan yang homogen dapat membantu penyebaran zat aktif terdistribusi secara optimal dan memberikan rasa yang nyaman ketika diaplikasikan pada kulit (Adnan, 2016).

Kemudian uji $\mathrm{pH}$ bertujuan untuk mengevaluasi sediaan yang dibuat mempunyai nilai $\mathrm{pH}$ berada pada rentang yang sesuai dan dapat diterima oleh kulit. Hasil uji $\mathrm{pH}$ dapat dilihat pada tabel 4. Nilai $\mathrm{pH}$ memenuhi persyaratan uji, dimana persyaratan $\mathrm{pH}$ kulit berada pada rentang 4-8 (Supomo dkk dalam Wasiaturrahmah, 2018). Nilai $\mathrm{pH}$ suatu sediaan yang terlalu basa dapat menyebabkan kulit menjadi kering dan kasar sedangkan apabila nilai $\mathrm{pH}$ terlalu asam dapat menyebabkan iritasi pada kulit (Kharisma, 20I4). Dari hasil One Way Anova diperoleh nilai signifikan tiap formula $\mathrm{p}<0,05$. Sehingga terjadi perbedaan signifikan antar konsentrasi ekstrak. Kemudian dilanjutkan dengan dengan uji Post Hoc Tukey untuk melihat kelompok mana yang mengalami perbedaan. Hasil uji Post Hoc Tukey menunjukkan $\mathrm{pH}$ formula I dan formula 2 tidak berbeda signifikan. Hal ini dikarenakan nilai signifikansi $p>$ 0,05 . Sedangkan formula 3 berbeda signifikan dengan formula I dan formula 2.

Uji daya sebar bertujuan untuk mengukur kemampuan sediaan gel ketika diaplikasikan pada bagian kulit. Adapun hasil uji daya sebar dapat dilihat pada tabel 4. Kemampuan menyebar sediaan gel berada pada rentang 3-5 cm maka gel gergolong dalam sediaan yang semikaku (semistiff), namun jika diameter daya sebar antara $5-7 \mathrm{~cm}$, maka gel tergolong dalam sediaan yag semicair (semifluid) (Hastuty dkk., 2018). Selain itu, menurut Garg dkk.,(2002) daya sebar sediaan semipadat yang baik untuk penggunaan topikal berkisar pada diameter 3$7 \mathrm{~cm}$, sehingga berdasarkan literatur tersebut sediaan gel yang diperoleh pada penelitian ini termasuk dalam gel semikaku dan memenuhi persyaratan uji daya sebar.

Dari hasil One Way Anova diperoleh nilai signifikan $p<0,05$. Sehingga terjadi perbedaan signifikan antar konsentrasi ekstrak. Kemudian dilanjutkan dengan uji Post Hoc Tukey untuk melihat kelompok mana yang mengalami perbedaan. Hasil uji Post Hoc Tukey menunjukkan formula I berbeda signifikan dengan formula 2 dan formula 3 . Hal ini dikarenakan nilai signifikansi $\mathrm{p}<0,05$.

Uji daya lekat bertujuan untuk mengukur kemampuan sediaan selekat dan melapisi permukaan kulit ketika sediaan diaplikasikan pada kulit. Hasil uji daya lekat dapat dilihat pada tabel 4. Data hasil pengujian tersebut memenuhi persyaratan uji daya lekat yaitu lebih dari 4 detik (Hastuty dkk, 2018). Dari hasil One Way Anova diperoleh nilai signifikan $p>0,05$. Sehingga tidak terjadi perbedaan signifikan antar konsentrasi ekstrak dan tidak perlu dilanjutkan ke uji Post Hoc Tukey. Sehingga dapat disimpulkan bahwa ketiga formula gel mempunyai kestabilan daya lekat yang tidak berbeda signifikan.

\section{Pengujian Aktivitas Antiradikal Bebas Sediaan Gel}

Hasil uji aktivitas antioksidan gel ekstrak etanol daun bidara dapat dilihat pada tabel 4. Uji ini dilakukan untuk mengetahui seberapa besar aktivitas antioksidan yang dihasilkan dari gel ekstrak etanol daun bidara. Aktivitas antioksidan diuji menggunakan meode DPPH karena merupakan metode yang sederhana, murah, peka, cepat dan membutuhkan sedikit sampel. Pada metode ini senyawa antioksidan yang berada pada ekstrak etanol daun bidara akan bereaksi dengan radikal bebas DPPH melalui mekanisme donasi atom hydrogen dan menyebabkan warna ungu pada DPPH akan berubah menjadi kuning (Hidayati, dkk., 2017).

Dari hasil pengukuran panjang gelombang diperoleh nilai $516 \mathrm{~nm}$ dengan absorbansi 0,5378. Selanjutnya dilakukan pengukuran untuk gel ekstrak etanol daun bidara. Dari tabel 5, dapat dilihat nilai ICso pada 3 formula gel esktrak etanol daun bidara yaitu I679,874 ppm; I203,636 ppm; dan 998,736 ppm, termasuk dalam kategori antioksidan lemah. Menurut Yen, dkk (200I) dalam Zulkarya (2018), aktivitas antioksidan dianggap lemah apabila nilai IC50 lebih dari 500 ppm. Kekuatan antioksidan sediaan gel lebih lemah dibandingkan vitamin C. Hal ini disebabkan karena vitamin $\mathrm{C}$ merupakan senyawa murni hasil isolasi yang memiliki aktivitas antioksidan sangat kuat sedangkan sediaan gel dengan zat aktif ekstrak etanol daun bidara yang merupakan campuran senyawa dengan khasiat yang beragam (Fitriani dkk, 2019).

Tabel 5. Hasil Uji Aktivitas Antiradikal Bebas Sediaan Gel Ekstrak Etanol Daun Bidara

\begin{tabular}{ccc}
\hline Sampel & Absorbansi & IC 50 \\
\hline DPPH & 0,5378 & Kontrol \\
FI $(4 \%)$ & 0,3491 & I679,874 \\
F2 (5\%) & 0,2950 & I203,636 \\
F3 (6\%) & 0,2892 & 998,736 \\
\hline
\end{tabular}

Penurunan aktivitas antioksidan tersebut dipengaruhi oleh kurang maksimalnya pelepasan zat 
aktif dari basis pada saat bereaksi dengan DPPH ketika pengujian aktivitas antioksidan. Selain itu, faktor lain yang dapat mempengaruhi penurunan aktivitas antioksidan sediaan gel adalah adanya proses pemanasan dalam pembuatan sediaan gel yang memungkinkan adanya kehilangan zat aktif sehingga perlu peningkatan konsentrasi zat aktif yang ditambahkan dalam sediaan agar jumlah bahan aktif yang berdifusi melewati ikatan polimer dari basis sediaan juga meningkat dan mampu memberikan efek yang diinginkan (Zulkarya dan Hastuti, 2018).

Aktivitas peredaman radikal bebas dari sediaan gel ditandai dengan penurunan intensitas warna ungu. Penurunan intensitas warna tersebut dapat disebabkan oleh keberadaan senyawa metabolit sekunder yang terdapat dalam daun bidara meliputi flavonoid, alkaloid dan tanin. Reaksi peredaman radikal bebas oleh senyawa flavonoid seperti dalam gambar I.

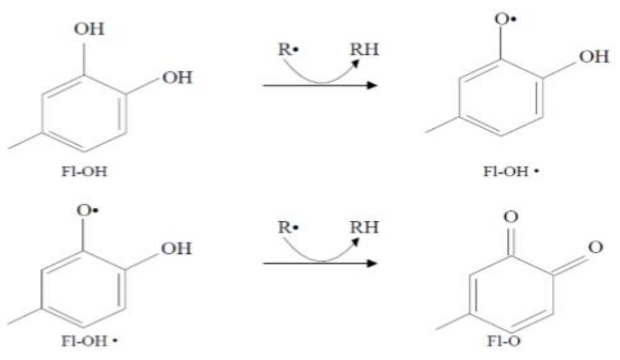

Gambar I. Reaksi Peredaman Radikal Bebas oleh Senyawa Flavonoid (Ridho, 20I3).

\section{Simpulan dan Saran}

Sediaan gel ekstrak etanol daun bidara konsentrasi 4\%, 5\% dan 6\% menunjukkan bahwa sediaan memenuhi persayaratan uji sifat fisik sediaan gel dengan nilai IC50 berturut-turut adalah I679,874 ppm, 1203,636 ppm, dan 998,736 ppm dan tergolong ke dalam antioksidan lemah.

Berdasarkan penelitian yang dilakukan perlu dilakukan studi lanjutan seperti uji kualitatif metabolit sekunder yang lain yang diduga memiliki aktivitas dalam menghambat radikal bebas serta dilakukan uji stabilitas, viskositas, iritasi dan toksisitas sediaan gel ekstrak etanol daun bidara.

\section{Daftar Pustaka}

Ardana, M., Vebry, A., dan Arsyik, I.. (2015). Formulasi Dan Optimasi Basis Gel Hpme (Hidroxy Propyl Methyl Cellulose) Dengan Berbagai Variasi Konsentrasi. J. Trop. Pharm. Chem; 3(2), I-8.

Fauzi, N.P., Sulistiyaningsih, dan Runadi, D. (2017). Uji aktivitas antibakteri ekstrak etanol dan fraksi daun jewer kotok (Coleus atropurpureus (L.) Benth.) terhadap bakteri Propionibacterium acnes ATTC I223 dan Staphylococcus epidermidis ATTC I2228. Farmaka; I5(3), 45-55.

Fitriani, N., Herman dan Rijai, L. (2019). Antioksidan Ekstrak Daun Sumpit (Brucea javanica (L). Merr) dengan Metode DPPH. Jurnal Sains dan Kesehatan; 2(I), 57-62.

Garg, A., Aggarwal, D., Garg, S., dan Singla, A. K. (2002). Spreading of semisolid formulations: An update. Pharmaceutical Technology North America; I2(9), 84-

Hastuty, H. S. B., Purba, P. N dan Nurfadilah, E. (2018). Uji Stabilitas Fisik Formulasi Sediaan Gel Ekstrak Daun Ketepeng Cina (Cassia Alata L) Dengan Gelling Agent $\mathrm{Na}$ Cmc Terhadap Staphylococcus Aureus Atcc 230840. Jurnal Gema Kesehatan; IO(I), 22-27.

Hidayati, N.D., Arifin, I., Yuni, A., Amalina, D dan Nur, K.A. (2017). Pengujian Aktivitas Antioksidan Ekstrak dan Fraksi Jantung Pisang Mas (Musa acuminta Colla) Menggunakan Metode DPPH. Pharmacy; I4(I), 75-85.

Ismarani, D., Liza, P., dan Indri, K. (20I4). Formulasi Gel Pacar Air (Impatiens balsamina Linn.) terhadap Propionibacterium acnes dan Staphylococcus epidermidis. Pharmacy Sciences Research; I(I), 30-45.

Kharisma, M. I. (20I4). Formulasi dan Uji aktivitas Antioksidan Sediaan Peel-Off Ekstrak Etanol 50 \% Kulit Buah Manggis (Garcinia mangostana L.). Skripsi. Jakarta : UIN Syarif Hidayatullah Jakarta.

Koirewoa, Y.A., Fatimawali,, dan Wiyono, W.I., (2012). Isolasi dan identifikasi senyawa flavonoid dalam daun beluntas (Pluchea indica L.). Pharmacon. I(I), 47-52.

Kurnia, N.H., dan Taufikurohmah, T. (2017). Pengaruh Penambahan Nanosilver Terhadap Aktivitas Antioksidan Nanogold dalam Meredam Radikal Bebas. Journal of Chemistry; 6(3), I6I-I65.

Maysuhara, S., (2009). Rahasia Cantik, Sehat dan Awet Muda, Edisi I. Yogyakarta: Pustaka Panasea.

Maakh, Y. F., and Maria, Y. L. (2018). Formulation and Antioxidant Activity Solid Bath Soap Ethanol Extract of Bidara Leaves (Ziziphus mauritiana Lamk). Health Polytechnic of 
Ministry International Conference; I(I), 49I-502.

Nabi, S.A.A., Muhammad, A.S., Sofia, A., Nafeesa, M., dan Iqbal, A. (2016). Pharmaceutical Gels: A Review. RADS-JPPS; 4(I), 40-48.

Padmasari, P.D., Astuti, K.W., dan Warditiani, N.K. (2013). Skrining Fitokimia Ekstrak Etanol 70\% Rimpang Bangle (Zingiber purpureum Roxb.). Jurnal Farmasi Udayana; I-6.

Prasetyo dan Inoriah, E., (2013) Pengelolaan Budidaya Tanaman Obat - Obatan (Bahan Simplisia). Bengkulu: Badan Penerbitan Fakultas Pertanian UNIB

Rahmi, Hanifah, Ramadhan, Rizky dan Radjab, dan Naniek Setiadi. (2017). Pengaruh Konsentrasi Natrium Alginat Terhadap Gel Ekstrak Daun Teh Hijau (Camellia sinensis L.) sebagai Inhibitor Tirosinase. Pharmacy; I4(2), I62-I72.

Ridho, Ely Ar. (2013). Uji Aktivitas Antioksidan Ekstrak Metanol Buah Lakum (Cayratia Trifolia) Dengan Metode DPPH (2,2Difenil-I-Pikrilhidrazil). Skripsi. Pontianak : Universitas Tanjungpura.

Risnadewi, W.N., Muliasari, H., Hamdin, C.D dan Andayani, Y. (2019). Uji Comparative Antioxidant Activity of Brucea javanica (L) Merr Seed Extract Derived from Maceration and Soxhletation Method. Proceedings of the 2nd International Conference on Bioscience, Biotechnology, and Biometrics; I-7.

Tiwari, P., Kumar, B., Kaur, M., Kaur G. \& Kaur H. (20II), Phytochemical Screening And Extraction: A Review. International Pharmaceutical Science; I(I), 98-I06.

Wasiaturrahmah, Y dan Jannah, R. (2018). Formulasi Dan Uji Sifat Fisik Gel Hand Sanitizer Dari Ekstrak Daun Salam (Syzygium Polyanthum). Borneo Journal Of Pharmascientech; 2(2), 87-94.

Zulkarya, L. G dan Hastuti, E. D. (2018). Formulasi Sediaan Krim Ekstrak Etanol Rumput Laut Coklat (Padina australis) dan Uji Aktivitas Antioksidan Menggunakan DPPH. Cendekia Journal of Pharmacy; 2(I), 8I-9I.

Zeng, Y., Deng, M., Lv, Z., and Peng, Y. (2014). Evaluasi of Antioxidant Activities of Extracts From I9 Chinese Edible Flowers. SpringerPlus; 3(3I5), I-5. 